\title{
The Methodology of the Department of Fuel and Energy Resources of the Enterprise Based on Fuzzy Logic
}

\author{
Valeriya E. Osipova and Dmitrij A. Yakovlev* \\ Zabaikalsky Railway Transport Institute \\ 11 Magistralnaya Str., Chita, Zabaikalsky krai, 672040, Russia
}

Received 27.02.2018, received in revised form 03.11.2018, accepted 08.02.2019

The paper proposed an effective model of management of fuel and energy enterprises, developed on the basis of fuzzy logic, allowing to minimize the risks associated with incorrect forecasting of energy consumption, allowing to consider not only quantitative but also qualitative indicators of the enterprise.

Keywords: fuel and energy complex, energy efficiency, energy economy, fuzzy logic, management.

Citation: Osipova V.E., Yakovlev D.A. The methodology of the department of fuel and energy resources of the enterprise based on fuzzy logic, J. Sib. Fed. Univ. Eng. technol., 2019, 12(2), 153-158. DOI: 10.17516/1999-494X-0124.

\section{Методология управления}

топливно-энергетическими ресурсами предприятия

на основе нечеткой логики

В.Э. Осипова, Д.А. Яковлев

Забайкальский институт железнодорожного транспорта Россия, 672040, Забайкальский край, Чита, ул. Магистральная, 11

В статье предложена эффективная модель управления топливно-энергетическими ресурсами энергетического комплекса предприятия, разработанная на основе аппарата нечеткой логики, позволяющая минимизировать риски, связанные с неправильностью прогнозирования расхода энергоресурсов, и учесть при этом не только количественные, но и качественные показатели работы предприятия.

Ключевые слова: топливно-энергетический комплекс, энергоэффективность, энергосбережение, нечеткая логика, управление.

(C) Siberian Federal University. All rights reserved

This work is licensed under a Creative Commons Attribution-NonCommercial 4.0 International License (CC BY-NC 4.0).

* Corresponding author E-mail address: Valeri3307@mail.ru 
Large industrial enterprises are defined by a branchy structure of power facilities. The basic kinds of energy resources consumption are electric energy, hot and cold water, and condensed air. Coal, combustion fuel oil, natural gas are used for heat energy production in the own boiler rooms. The production of condensed air is carried out in pump stations using electric energy. The diagram of fuel and energy consumption after the example of railway transport objects is presented in Fig. 1.

Analysis of the existent expenditures after the example of railway transport objects shows the energy expenditures to be one of the most prominent components of the constant enterprise's expenditures. Therefore the important matter of any organization is not only supply reliability and energy resources quality but also the problem of its cost. At present there are two ways of cutting the enterprise's production costs including the choice of more profitable price policy for settling with energy resources providers or optimization of energy consumption.

The right forming of fuel and energy resources order excludes the equipment's idle time and commercial lasses connected with short or over order of one or another sort of energy resources.

The management of the enterprise's fuel and energy complex is directed at the forming the fuel and energy balance providing regular supply of consumers [1,2]. The process of the enterprise's fuel and energy resources management (Fig. 2) represents a multilevel system including the stages of planning, prediction, and monitoring of interdependent parameters.

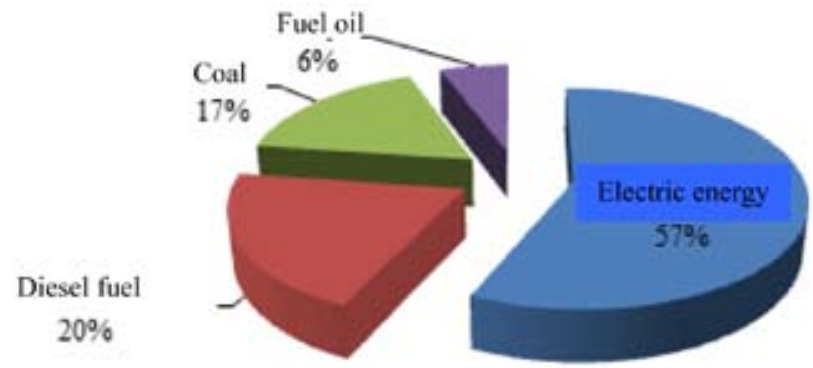

Fig. 1. Diagram of fuel and energy consumption after the exemple of railway transport objects

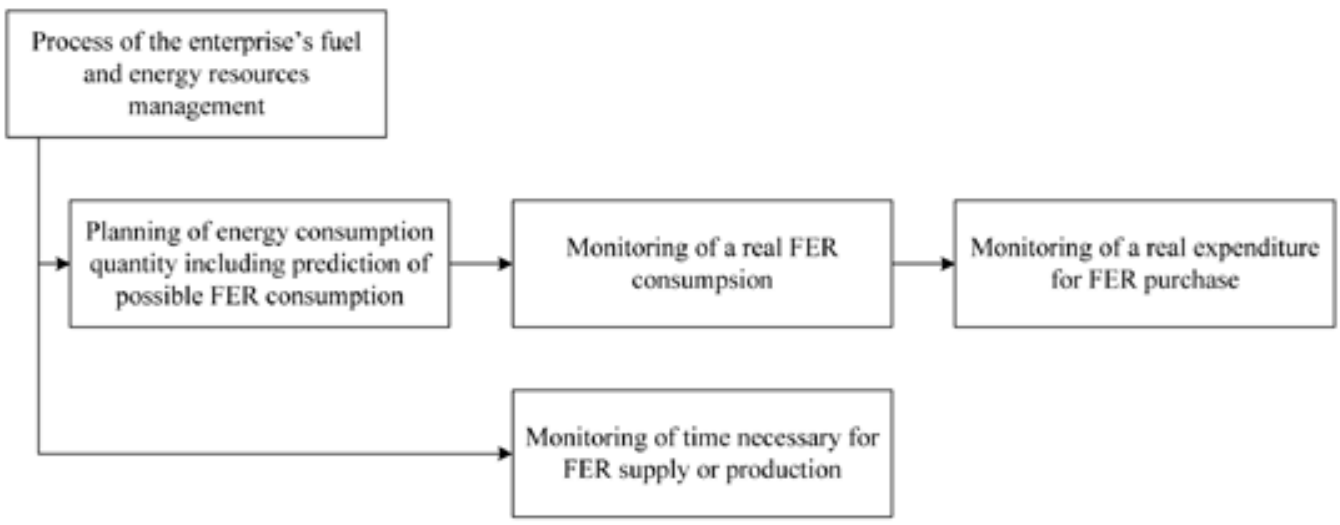

Fig. 2. Process of enterprise's fuel and energy complex management 
The main difficulty of the modern enterprise's fuel and energy complex management lies in the imperfection of its calculation and consumption rating. No less important reason of a low efficiency of the fuel and energy complex management is in the absence of management solution acceptance system for its effective use.

The existing management methods enterprise's fuel and energy complex can be conditionally divided into two groups: traditional, management methods and another, based on artificial intellect, which classification is presented in Fig. 3.

Analysis of the traditional methods of the enterprise's fuel and energy complex management illustrates that, at present, the fuel and energy balance forming is realized on the basis of expert's opinion, prediction values and theory of constraints [3-5]. In spite of all this, the order forming on the basis of prediction values is more developed, classification of which is presented in Fig. 4.

Existing methods of forming of the enterprise's fuel and energy balance have a number of significant disadvantages such as the impossibility of accounting for short-term changes in the process of work, neither the existence of a large amount of reliable statistical data characterizing the state of the facility, or the availability of competent experts on the basis of the opinions of which an order will be issued. These methods have a lack of the ability of modeling and evaluating of various options or there is no possibility of predicting various types of enterprise's energy recourses as well.

Taking into consideration all the drawbacks of the existing methods of the enterprise's fuel and energy complex management, the authors put forward a fuzzy logic management model connected with science-based technical and technological solutions (methods and algorithms), the introduction of which will make a significant contribution of increasing of the enterprise's energy efficiency and/or the region. The enterprise's energy efficiency is shown in Fig. 5 [6, 7].

The validity of application fuzzy logic for fuel and energy complex management is enplaned by a number of factors connected with parameters describing the initial state of the object (Fig. 6)

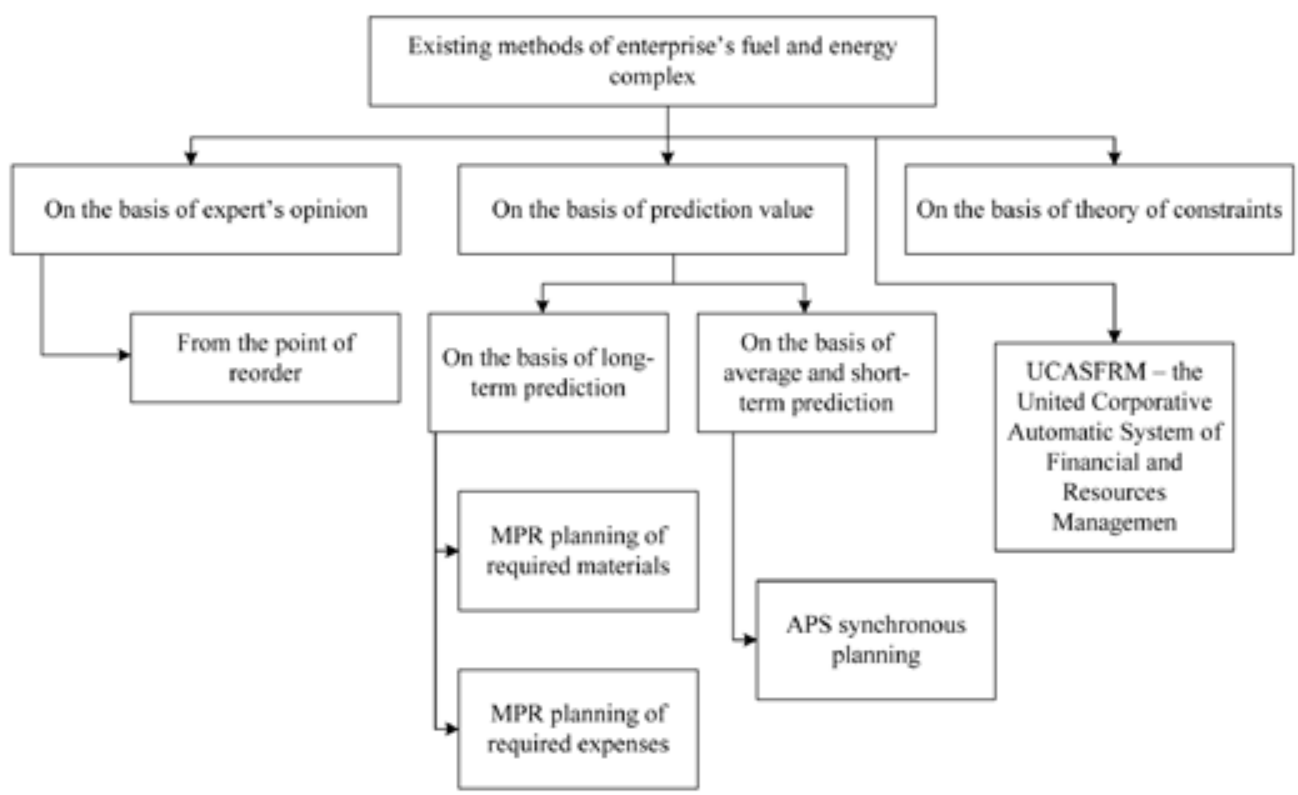

Fig. 3. Classification of the existing methods of enterprise's fuel and energy complex management

$$
-155 \text { - }
$$




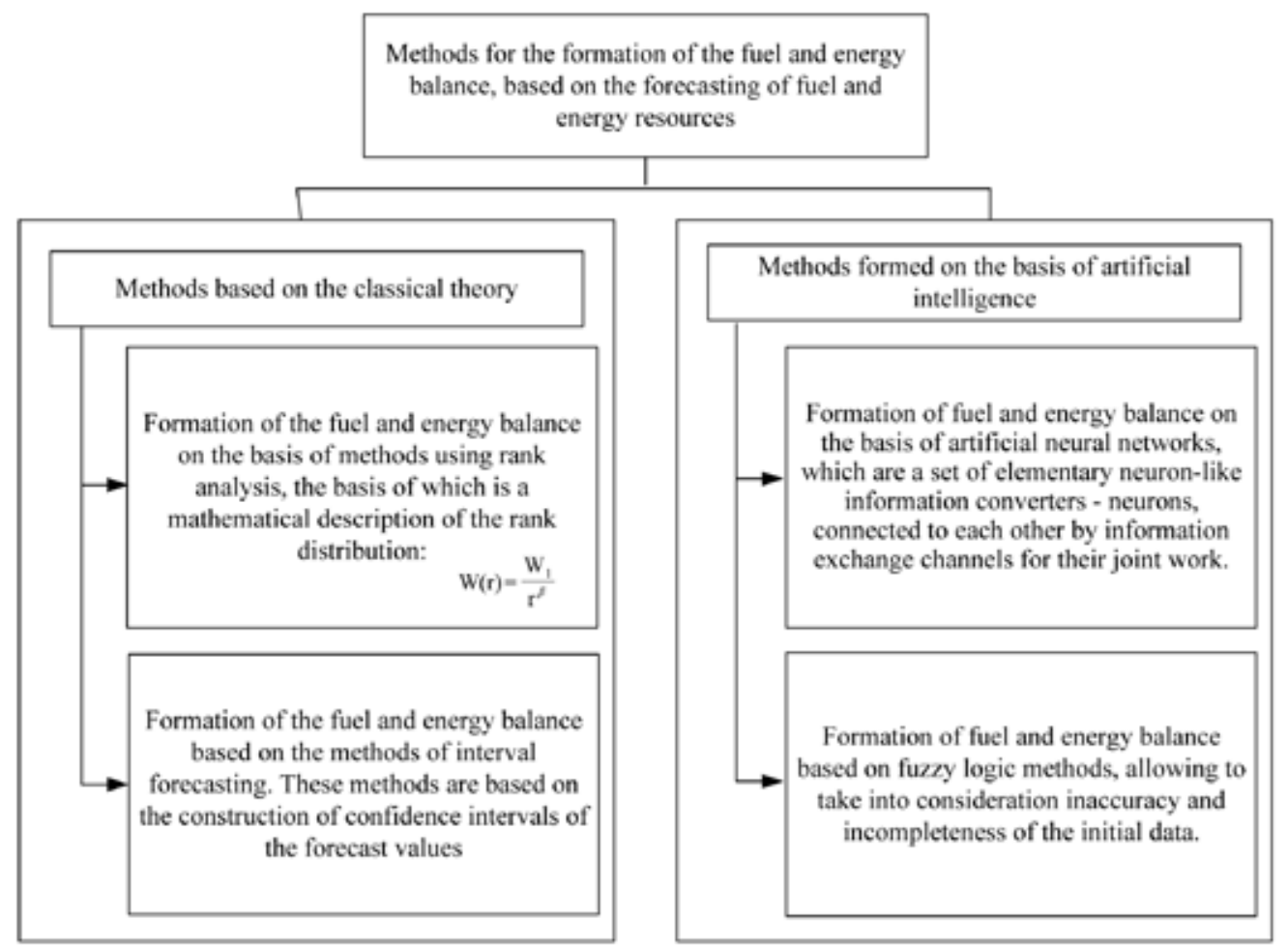

Fig. 4. Classification of existing methods of the enterprise's fuel and energy complex management

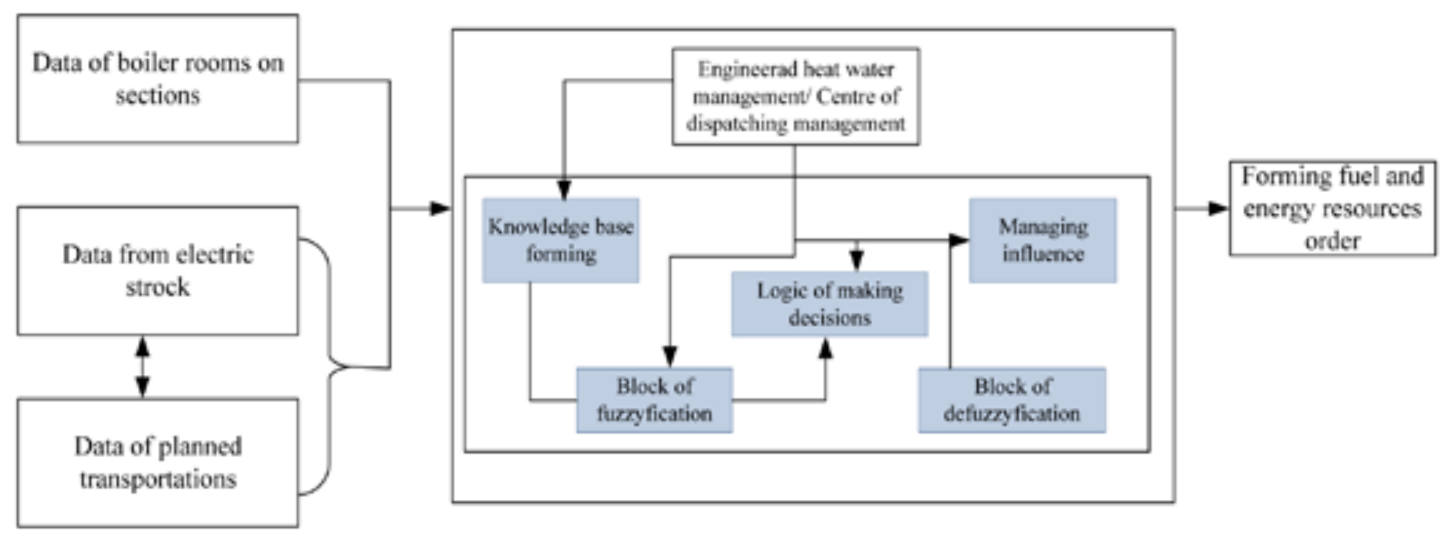

Fig. 5. Structural diagram of the enterprise's fuel and energy complex management model

The detailed diagram of the suggested model of the enterprise's fuel and energy complex management is presented in Fig. 7. The suggested model of management is directed at the risk minimization connected with prognosis incorrectness of energy consumption taking into account not only quantitative but also qualitative indices of enterprise's work.

According to the presented diagram, the order forming takes place with calculation of critical point of the existing fuel and energy resources reserves, in spite of this, in the process there is the possibility of critical/ anomalous parameters calculation. In the process of the forming fuel and energy 


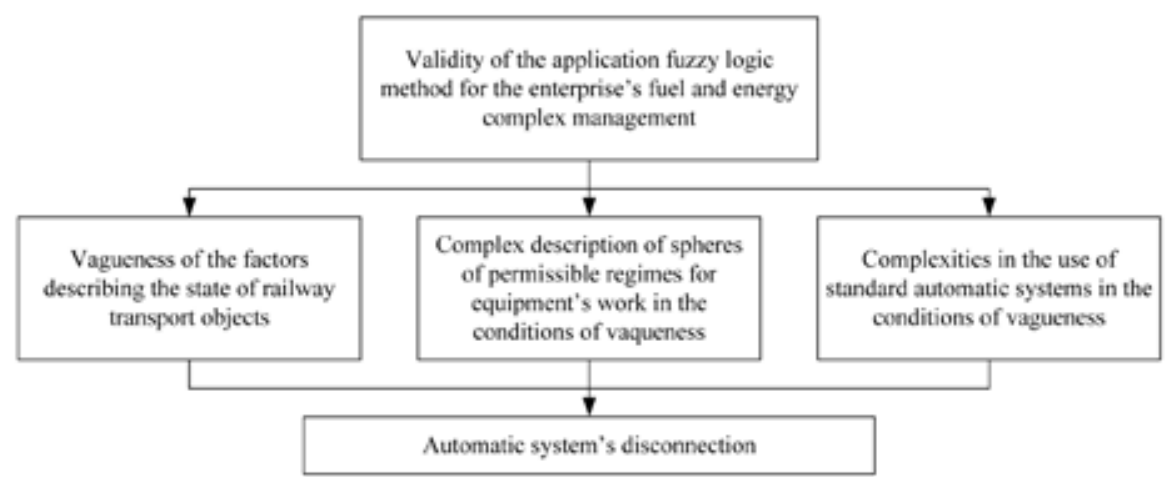

Fig. 6. Validity of the fuzzy logic apparatus use for the enterprise's fuel and energy complex management

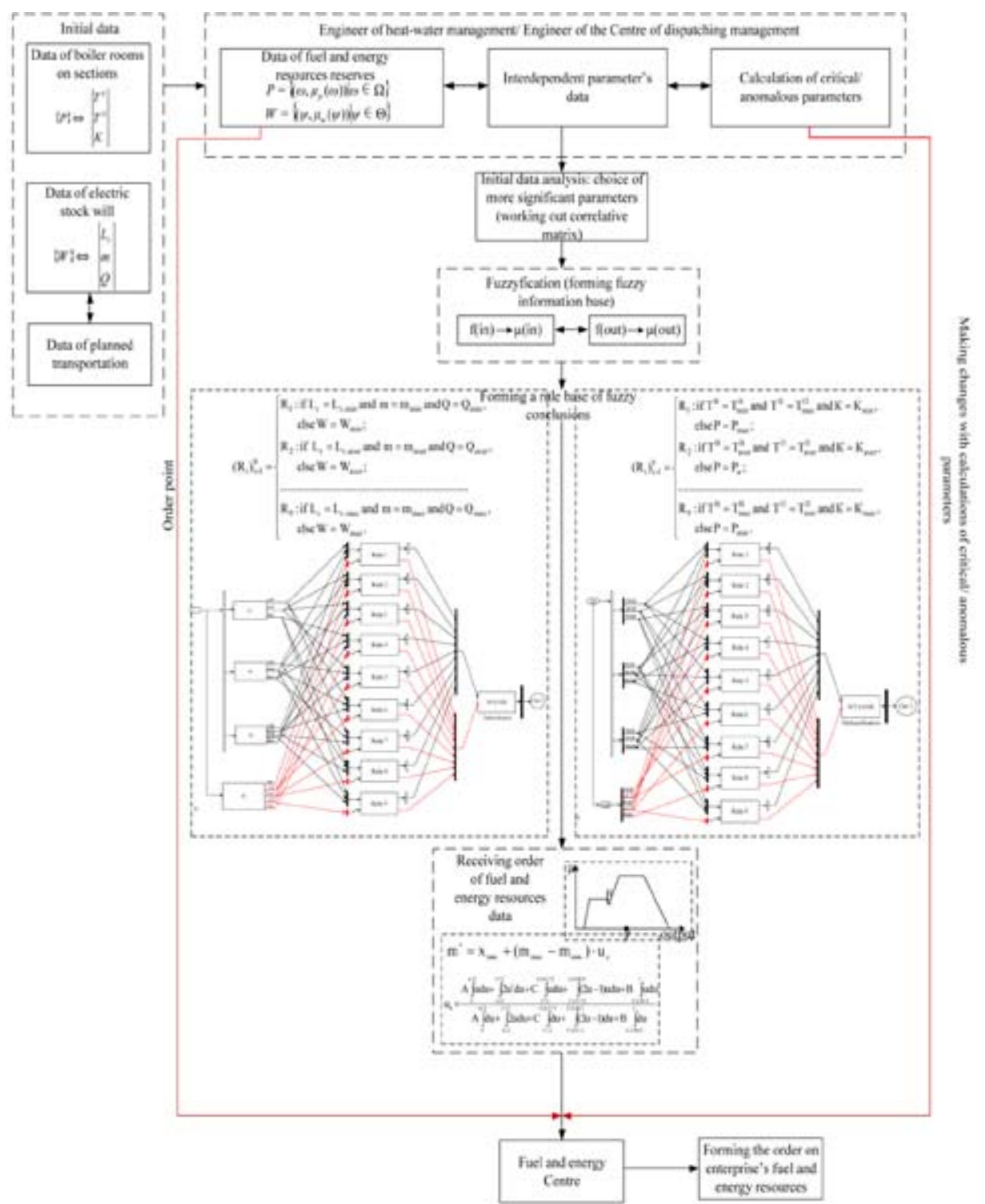

Fig. 7. The detailed diagram of the enterprise's fuel and energy complex management 
balance suggested model allows to rely on the energy consumption prognosis data for the definite period taking into account, in case of need, the opinion of an experienced expert.

The effectiveness of a suggested management model was tested on the example of railway transport objects. Findings of the calculations allowed to come to a conclusion that taking into account the pricing policy in conformity with electrical energy, the average profit of the suggested model production accounts for $2-4 \%$ of operation expenses on electrical energy purchases, which illustrates a high economic effectiveness of the suggested enterprise's fuel and energy complex management model.

\section{References}

[1] Osipova V.E., Yakovlev D.A. Application of fuzzy control the energy supply of the enterprises, Prog. Problems of the transfer of modern technologies to the economy of the Baikal region and rail transport, Chita, 2011.

[2] Osipova V.E., Yakovlev D.A. The application of fuzzy logic in the management of energy resources on the example of TRANS-Baikal railway, Prog. Transport infrastructure of the Siberian region, Irkutsk, 2011.

[3] Arnold J., Chapman S. Introduction to human resource management. M.: Bmikro, laboratory of programming and publishing, 2003. $500 \mathrm{p}$.

[4]Piterkin S.V., Oladov N.A, Isaev D.V.Justintimefor Russia. The practice of applying ERP systems. 3rd ed. M.: Al'pina Pablisherz, 2010. 368 p.

[5] Tulupov L. P., Zhukovsky E.M., Gusyatiner A.M. Automated system for managing the transportation processes on the Railways: studies. manual for universities. M.: Transport, 1991. $208 \mathrm{p}$.

[6] Osipova V.E. Implementation of fuzzy logic algorithm in the analysis and planning of fuel and energy resources consumption systems of energy supply of the enterprises. Prog. Transport infrastructure of the Siberian region. Irkutsk, 2015.

[7] Osipova V.E., Komogorcev M.G. The use of neural networks and coordinate definition of the location of the automated trains for the quick calculation of intervals between consecutive trains. Prog. Transport infrastructure of the Siberian region. Omsk, 2016. 